culoskeletal patients. In: Badley EM, Williams JI (Eds.), Patterns of Health Care in Ontario: Arthritis and Related Conditions. Toronto: Institute for Clinical Evaluative Sciences, 1998.

3. Jaeger FJ. Strategic planning, an essential management tool for health care organizations, and its epidemiologic basis. In: Oleske DM (Ed.), Epidemiology and the Delivery of Health Care Services. New York: Plenum Press, 1995.

4. Sarkella J. Demographic profile. In: Alder R, Vingilis E, Mai V (Eds.), Community Health and Well-being in Southwestern Ontario. A Resource for Planning. London: Middlesex-London Health Unit and the Faculty of Medicine, University of Western Ontario, 1996.

5. Chesworth HM. Acute Care Length of Stay and Post-Acute Discharge Destination Following Hip Fracture, Thames Valley District Health Council [thesis]. London, ON: University of Western Ontario, 2000.

6. Health Services Restructuring Commission. London Health Services Restructuring Report. Toronto: Health Services Restructuring Commission, 1997.
7. Health Services Restructuring Commission. Rebuilding Ontario's Health System: Interim Planning Guidelines and Implementation Strategies. Home Care, Long Term Care, Menta Health, Rehabilitation, Sub-Acute Care. A Discussion Paper. Toronto: Health Services Restructuring Commission, 1997.

8. Lamb GS. Outcomes across the care continuum. Medical Care 1997;35(11): NS106- NS114.

9. Leatt P, Pink GH, Naylor CD. Integrated delivery systems: Has their time come in Canada? Can Med Assoc J 1996;154(6):803-9.

10. Jaglal SB. Osteoporotic fractures: Incidence and impact. In: Badley EM, Williams JI (Eds.), Patterns of Health Care in Ontario: Arthritis and Related Conditions. Toronto: Institute for Clinical Evaluative Sciences, 1998.

11. Puckett CD. The Educational Annotation of ICD9-CM. Reno: Channel Publishing, 1998.

12. Chesworth BM, Speechley M, Hartford K, Crilly R. Relationship between acute care hospitalbased factors and discharge destination for rehabilitation following a hip fracture. Can J Aging 2001 (In press).
13. Charlson ME, Pompei P, Ales KL, MacKenzie CR. A new method of classifying prognostic comorbidity in longitudinal studies: Development and validation. I Chron Dis 1987;40(5):373-83

14. Deyo RA, Cherkin DC, Ciol MA. Adapting a clinical comorbidity index for use with ICD-9$\mathrm{CM}$ administrative databases. J Clin Epidemiol 1992;45(6):613-19.

15. Canadian Healthcare Association. Guide to Canadian Healthcare Facilities Volume 7 19992000. Ottawa: Canadian Healthcare Association, 1999.

16. Dawson-Saunders B, Trapp RG. Basic \& Clinical Biostatistics. East Norwalk: Appleton \& Lange, 1994.

17. SAS Release 6.12. Cary, NC: SAS Institute, 1996.

Received: October 31, 2000

Accepted: June 14, 2001

\begin{tabular}{llllllllll}
\hline $\mathrm{B}$ & $\mathrm{O}$ & $\mathrm{O}$ & $\mathrm{K}$ & $\mathrm{R}$ & $\mathrm{E}$ & $\mathrm{V}$ & $\mathrm{I}$ & $\mathrm{E}$ & $\mathrm{W}$ \\
$\mathrm{R}$ & $\mathrm{E}$ & $\mathrm{C}$ & $\mathrm{E}$ & $\mathrm{N}$ & $\mathrm{S}$ & $\mathrm{I}$ & $\mathrm{O}$ & $\mathrm{N}$ \\
\hline
\end{tabular}

\title{
Health Promotion Planning: An Educational and Ecological Approach (3rd ed)
}

L.W. Green, M.W. Kreuter (Eds.) Mountain View, CA: Mayfield Publishing Company, 1999; 621 pp.

Dramatic changes in the field of health promotion and widespread application of the PRECEDE-PROCEED model provided impetus for Green and Kreuter to launch the $3^{\text {rd }}$ edition of their text. Their aim is to document changes within the field but also to capture some of the diverse applications of the model. Revisions to the subtitle of the text are reflective of some of those changes in the field; a shift away from an educational focus ( $1^{\text {st }}$ edition), to an environmental ( $2^{\text {nd }}$ edition) and more recently an ecological approach to health promotion planning.

The authors describe the historical context of health promotion and the basis for the PRECEDE-PROCEED model (Chapter 1), the phases of the model (Chapters 2-7) and its applications (Chapters 3-11), and an overview of public health informatics as well as technological applications of the model (Chapter 12). There are subtle but significant changes from the $2^{\text {nd }}$ edition that reflect the authors' change in orientation. They attempt to shift from using the language of "diagnosing" problems to "assessing" problems and assets but remnants of a problemfocused clinical orientation continue to surface. The emphasis throughout the book is on developing reciprocal relationships and partnerships with community and distinguishing between real or symbolic community participation. There are also more concise descriptions of assessment methods and somewhat more emphasis on strategies for utilization of the data generated from the phases of assessment.

The PRECEDE assessment phases direct initial attention to outcomes rather than inputs, and thus encourage planners to critically examine why a given initiative should be implemented. The framework reflects the multidisciplinary nature of health promotion and as such is a valuable tool for people engaged in health promotion planning regardless of their disciplinary background. It is assumed that those who apply the model have grounding in the scientific foundations of health promotion (i.e., social and behavioural sciences, biomedical sciences, economics, and management sciences). The need for a working knowledge of these areas is reflected in the PRECEDE phases of assessment (i.e., social, epidemiological, behavioural and environmental, educational and ecological, and administrative and policy phases) and the PROCEED phases of implementation and evaluation.

As with previous editions, this text is a valuable resource for those engaged in implementing and planning health promotion programs. Revisions made in this edition reflect the need to remain responsive to social, political and economic contexts.
Cathie M. Scott, PhD
University of Calgary
Faculty of Medicine
Community Health Sciences
3300 Hospital Drive NW.
Calgary, Alberta 